\title{
An Analysis of Teacher Strategies on The Eleventh Grade Students Learning Activities in EFL Classroom at SMA Babus Salam Tangerang
}

\author{
Deni Iskandar ${ }^{1}$ Lusiana $^{2}$ \\ ${ }^{1}$ STIT Misbahul Ulum \\ deniiskandar.elt@gmail.com \\ ${ }^{2}$ University of Muhammadiyah Tangerang \\ lusiana.izye@gmail.com
}

\begin{abstract}
Research on "An Analysis of teacher's strategies on the eleventh-grade students learning activities in EFL classroom at SMA Babus Salam" aimed at finding out the strategies that had been implemented by the English teacher related to the complexity of students in the Islamic boarding school. The approach used in this research was qualitative approach with intrinsic case study as its method. The instrument used in this research was observation and interview. The findings revealed that the English teacher did not rely on specific strategy from the particular method but she used various strategies in order to accomplish the objective of the learning. In addition, the findings also showed that the strategies had helped the students internalizing what they had learned into a real practice. Also, the strategies have provided them with sufficient exposure and opportunity to practice the target language and to accomplish the objective of the learning.
\end{abstract}

Keywords: intrinsic case study, teaching strategies, objective of the learning

\section{INTRODUCTION}

A discussion over English learning has been ongoing for ages. English learning gained the position in twentieth century where the applied linguists sought to design principles and procedures for teaching methods and materials drawing on the developing fields of linguistics and psychology (Richard: 2001). Consequently, there has been many approaches and methods to tackle the compelling matters in language learning, such as: Grammar Translation Method, Audio Lingual Method, Communicative Language Learning, Task Based Learning, Project Based Learning, and many others. These methods and approaches are intended to help make more productive and effective learning (Richard: 2001, Nunan: 2004, Harmer: 2007, Brown: 2007, Freeman: 2008, Abbasi: 2011).

With the diversity of provided methods, other challenges always come up. Teachers are still demanded to be more creative and adaptive in classroom situation. As classroom situation was not always predictable, teachers must be well adapted to any unexpected things in the classroom and at the same time, he or she should be able to accommodate various roles that suit to the situation in the classroom (Harmer: 2007, Christison: 2011, S. Archana \& K. Usha Rani: 2016). This was due to one method might work in one classroom and might fail when applied in another classroom and a teacher is not merely transferring knowledge focuses on one approach only, but should be able to be well adapted to various ways of strategies (Brown: 2000). For instance, problems that have always been encountered by the $11^{\text {th }}$ grade students of Babus Salam Senior High School at Islamic boarding school in Tangerang are students' physical condition due to exhaustion, mixed ability students in one classroom, and their motivation in learning English. Exhaustion or fatigue was surely encountered by the students who spend all of their time in the dormitory provided by the boarding school. Further, their sleeping time was limited to 6 hours only because they must perform dawn praying together. These overwhelming activities have surely tired them down; consequently, they were exhausted during the lesson and frequently fell asleep. Also, the diversity in the students' English level must be taken into account. As the teacher must be aware of students' English level diversity to create effective learning process and equip it with various appropriate strategies (Piller and Skilling: 2005, 
Irby, et.all: 2008, Thompson: 2012). In this boarding school, not all students were good in English since it adapts both English and Arabic language as their daily languages. Some are good in English but poor in Arabic; on the other hand, some were good in Arabic language, but they were poor in English language. The rest of them might not be good in neither of them. As a result, this level diversity in English skill will affect the students' absorbance of the lesson if proper and meticulous activities are not well applied. Finally, the students' motivation in learning is different from each individual. This factor might be due to their animosity toward English language and their fossilized paradigm that English was very hard to learn. Considering these phenomena, this research aims to investigate teacher's strategies in order to meet the objective of the learning and how the strategies work in assisting the students to achieve the learning objective by taking account to the problems mentioned earlier.

\section{METHOD}

This research applied qualitative approach in order to seek meaning and study deeper the issue that was being investigated in a very natural setting (Patton and Cochran: 2002, Mack, et. all: 2005, Creswell: 2009, Fraenkel, Wallen and Hyun: 2012). The method used for this research is a case study; particularly intrinsic case study. In other word, the research obtained the data from one informant by investigating her daily teaching in the classroom, the lesson plan she had prepared, and her ways of dealing with problems during her teaching process (Lodico, Spaulding, and Voegtle: 2010).

The research was conducted for 3 months and the instrument used for this research consisted of interview guideline, observation and the field note. The question in interview focused on teacher's dilemma when teaching, problems that she faced in the classroom and her strategy to encounter the problems. Also, the observation is narrowed to five criteria; preparation, presentation, strategies in teaching activities, teacher's role, and teacher's interaction with the students in the classroom which was adapted from Richard's observation form (Richard, 2001). The data was analyzed through summarizing and coding them and it was finally triangulated. The result of this research has been peer reviewed and discussed by the colleagues in university of Muhammadiyah Tangerang and the English teacher in Babus Salam Islamic boarding school respectively.

\section{FINDINGS AND DISCUSSION}

The research was started by observing the teacher when she was teaching English subject in the classroom and there were 32 students in the classroom. The observation forms were used from scale 1-4 such as; unsatisfactory (1), average (2), above average (3), and excellent (4). The findings are indicated as follow:

Table: 1

\begin{tabular}{|c|l|c|c|c|c|}
\hline A. & \multicolumn{3}{|c|}{ Preparation (Evidence in Lesson Observation } & \multicolumn{3}{l|}{} \\
\hline \multirow{2}{*}{ NO. } & \multicolumn{1}{|c|}{ INDICATORS } & \multicolumn{1}{|l|}{ SCALES } & \\
\hline & & \multicolumn{1}{|c|}{ Presentation } & $\mathbf{2}$ & $\mathbf{3}$ & $\mathbf{4}$ \\
\hline 1 & The teacher was well prepared and well organized in the class & & $\checkmark$ & \\
\hline 2 & The lesson reviewed material and looked ahead to new material & & $\checkmark$ & \\
\hline 3 & The prepared goals or objectives were apparent & & $\checkmark$ & \\
\hline B. & \multicolumn{1}{|c|}{} & $\checkmark$ & & \\
\hline 4 & The teacher leads the class in well-prepared activities & $\checkmark$ & & \\
\hline 5 & The class material was explained in an understandable way & $\checkmark$ & & \\
\hline 6 & The lesson was smooth, sequenced and logical & & $\checkmark$ & \\
\hline 7 & The lesson was well-faced & & \\
\hline 8 & $\begin{array}{l}\text { Directions were clear and concise and students were able to carry } \\
\text { them out }\end{array}$ & $\checkmark$ & & \\
\hline 9 & Material was presented at the students' level of comprehension. & & $\checkmark$ & \\
\hline
\end{tabular}




\begin{tabular}{|c|c|c|c|c|}
\hline 10 & $\begin{array}{l}\text { An appropriate percentage of the class was student production of } \\
\text { the language }\end{array}$ & $\checkmark$ & & \\
\hline 11 & The teacher answered the questions carefully and satisfactorily. & $\checkmark$ & & \\
\hline 12 & $\begin{array}{l}\text { The method/s was/were appropriate to the age and ability of the } \\
\text { students. }\end{array}$ & $\checkmark$ & & \\
\hline 13 & $\begin{array}{l}\text { The teacher knew when the students were having trouble } \\
\text { understanding. }\end{array}$ & & $\checkmark$ & \\
\hline 14 & $\begin{array}{l}\text { The teacher showed an interest in, and enthusiasm for, the subject } \\
\text { taught }\end{array}$ & & $\checkmark$ & \\
\hline C. & Strategies in Teaching Activities & & & \\
\hline 15 & There were balance and variety in activities during the lesson. & $\checkmark$ & & \\
\hline 16 & The teacher was able to adapt to the unanticipated situation. & $\checkmark$ & & \\
\hline 17 & The teacher was able to adapt to the unanticipated situation. & $\checkmark$ & & \\
\hline 18 & Drills were used and presented effectively & $\checkmark$ & & \\
\hline 19 & $\begin{array}{l}\text { Structures were taken out of artificial drill context and applied to } \\
\text { the real context } \\
\text { of the students' culture and personal experience }\end{array}$ & $\checkmark$ & & \\
\hline 20 & The teacher applies strategies from Grammar Translation Method & $\checkmark$ & & \\
\hline 21 & The teacher applies strategies from Direct Method & $\checkmark$ & & \\
\hline 22 & The teacher applies strategies from Audio Lingual Method (ALM) & & $\checkmark$ & \\
\hline 23 & $\begin{array}{l}\text { The teacher applies strategies from Communicative Language } \\
\text { Teaching }\end{array}$ & & $\checkmark$ & \\
\hline 24 & $\begin{array}{l}\text { The teacher applies strategies from Task Based Language } \\
\text { Teaching method }\end{array}$ & $\checkmark$ & & \\
\hline D. & Roles of the Teacher & & & \\
\hline 25 & The teacher acted as the controller in the classroom & & $\checkmark$ & \\
\hline 26 & The teacher acted as the prompter in the classroom & & $\checkmark$ & \\
\hline 27 & The teacher acted as the participant in the classroom & & $\checkmark$ & \\
\hline 28 & The teacher acted as the resource in the classroom & $\checkmark$ & & \\
\hline 29 & The teacher acted as the tutor in the classroom & & $\checkmark$ & \\
\hline E. & Teacher Students Interaction & & & \\
\hline 30 & $\begin{array}{l}\text { Teacher encouraged and assured full student participation in the } \\
\text { class. }\end{array}$ & $\checkmark$ & & \\
\hline 31 & $\begin{array}{l}\text { The class felt free to ask questions, to disagree, or to express their } \\
\text { own idea. }\end{array}$ & $\checkmark$ & & \\
\hline 32 & The teacher was able to control and direct the class. & $\checkmark$ & & \\
\hline 33 & The students were attentive and involved & $\checkmark$ & & \\
\hline 34 & $\begin{array}{l}\text { The students were comfortable and relaxed, even during intense } \\
\text { intellectual activity. }\end{array}$ & & $\checkmark$ & \\
\hline 35 & The students were treated fairly, impartially, and with respect. & & $\checkmark$ & \\
\hline 36 & The students were encouraged to do their best & & $\checkmark$ & \\
\hline 37 & The teacher was relaxed and matter-of-fact in voice and manner. & & $\checkmark$ & \\
\hline 38 & The teacher was aware of individual and group needs. & $\checkmark$ & & \\
\hline
\end{tabular}

From the presentation indicator, the teacher mixed her teaching presentation with both Bahasa Indonesia and English language. She wanted to make sure the students understood the materials well. However, from this observation, the teacher talking time was still more dominant than the students 
talking time. In addition, the researcher also found that some students were sleepy and still could not understand the materials well. The next indicator is the strategies that the teacher used in teaching. The researcher found that the teacher has used varied strategies such as; the fill in the blank of the practice from the lyric she has given, the conversation practice where the students were asked to perform the conversation, questions and answers, dialogue completion, chain drill, repetition, drill, dialogue memorization, roleplay, problem solving and simulation. Furthermore, from the roles of teacher indicators, the teacher always model the target language before teaching, she also answered questions from the students, joined with the classroom activities, and always seemed to encourage the students to do their best in the practice. Finally, the teacher and students interaction, the students were quite encouraged to be active in the classroom but they were still hesitant due to fatigue and low English competency. Despite the teacher's well voice and manner, it still could not encourage them to be more active in the learning. In addition, the teacher was also aware of the group needs during learning.

The teaching strategies that have been applied by English teacher are scientific learning. Scientific learning according to Vice Ministry of Education (2014) is a learning that encourages the students to observe, inquire, associate, experiment and communicate through their personal experience and through collaborative learning. This learning strategies encourages the students to be more independent in learning and more aware of their learning process. Those five steps have been broken down further by the teachers into some language learning activities. For example, in term of observing and inquiring, the English teacher has asked the students to look at lyric and study it. The lyric was incomplete. The teacher then asked the students to predict what would be the best answer to complete the lyric. This activity is one of strategies that existed in the grammar translation method. Even though this method was regarded classic, many teachers still use this method. As Freeman (Freeman: 2008) said that the grammar translation method is classic and had been used by teachers for years. Also, in promoting active learning for the students, the teacher plays the role not only as the controller but also as the prompter and facilitator. It is indeed true that in language teaching, teacher must be able to play any role suitable for the students. Therefore, (Harmer: 2007, and Murray and Christison: 2011) agreed that teacher poses many roles from the manager of the classroom and the prompter. This strategy has also been endorsed by Thompson (Thompson: 2012). In her research on Language Teaching Strategies and Techniques Used to Support Students Learning in a Language other than Their Mother Tongue, she found that language teaching strategies and techniques used by the teachers during her observation are vocabulary check which is $21 \%$, eliciting which is $20 \%$, modelling on the target language which is $19 \%$, think aloud $13 \%$, modelling the activities $8 \%$, student-thinking-time $6 \%$, re-cast $5 \%$, and error correction $1 \%$.

In experimenting and associating the language, the teacher let the students do roleplay, questions and answer drill, dialogue completions, dialogue memorization, repetition drill and simulation. These were intended to see how the students absorbed the material that was being taught. Roleplay was teaching strategy taken from Communicate Language Teaching as it involves real communication promote learning; Therefore, learning activities are selected based on how well they engage the learner in meaningful and authentic language (Richard: 2001). Moreover, the questions and answer drill strategies are sourced from the direct method principles. Direct method is oral communication in the direct method was built up carefully around the question and answer exchange between the teachers and students in small, intensive classes. Further, dialogue completions, dialogue memorization, repetition drill are taken from the audio lingual method (Brown: 2000, Freeman: 2008). In simulation, the teacher led the students into certain situation such as; in the hotel and asked the students to create conversation based on the situation given to them. This strategy is taken from the Task Based Language Teaching (TBLT). TBLT refers to an approach based on the use of tasks as core unit of planning and instruction in language teaching (Richard and Rodgers: 2001). This strategy is divided the task in TBLT into two categories: pedagogical tasks and enabling skills. This pedagogical task includes rehearsal task and activation task and the enabling skills include language exercises and communicative activities that are in the pedagogical task (Nunan: 2004). So, basically, the strategy using Task Based Language Teaching (TLBT) can be implemented in the following:

a. Assigning tasks that that involve real world communication rehearsal rationale. 
b. Assigning communicative activities such as roleplay, problem solving, simulation and many other communicative activities as activation rationale.

Finally, to promote the communicative aspect in scientific learning, the teacher asked the students to implement what they have learned through role play and language games such as chain story and guided conversation. This strategy was in line with the communicative language teaching method as the goal of communicative language teaching is to develop the communicative competence (Richard and Rodger: 2001).

The strategies that the teacher has implemented were good and varied. They provided students with sufficient input of language practice to achieve the target language. This is because in language teaching, having sufficient exposure toward the language as much as possible would lead to better outcome for the students. This is in line with the English learning process according to the K-13 curriculum. The vice ministry of education (2014) stated that in K-13 curriculum, language is no longer taught based on the structure of the language itself, but it was designed to make students accustomed to using English expression and to make them accustomed to reading and understanding the text. These would require the students to be exposed frequently to achieve the habit of using English expression and understanding text. Therefore, the strategies that have been implemented by the teacher could be said as the breakdown of K-13 principles.

At the beginning of the lesson, the students were asked to observe the song and fill out the blank from the space provided into the lyric has helped the students to get their mind ready before beginning the lesson. Song can be used at any stage of a lesson and there are many ways to incorporate them into a lesson. Sometimes, they are used just as gap fillers and warm-ups, sometimes as the main part of a lesson, but sometimes they are there to provide a fun atmosphere (Dzanic: 2016). Teacher's role as manager of the class has assisted her to decide the flow of the class. Harmer (Harmer: 2007) said that when teacher acted as the manager or controller, they take the roll, tell the students things, organize drills, and many others. This kind of role has helped the students to be under controlled during the teaching and learning process. Also, the teacher played the role of the prompter has given the students an example of how language works in the classroom. Harmer (Harmer: 2007) also added that prompter would stimulate the learner in learning by guiding them and giving them the clue of the target language. In this sense, teacher's role as the prompter has helped the students to think creatively by trying to find the answer by themselves. When the teacher implemented the roleplay strategy, she has given the student an opportunity to practice the target language with their peers. They were given freedom to communicate with their peers within the limited context. Activities in communicative language teaching is unlimited, provided that such exercises provided the learner with the communicative objectives of the curriculum, engage learners in communication, sharing information, negotiation of meaning, and interaction (Richard and Rodger: 2001). Additionally, when the teacher did the question and answer drills, they have helped the learner to understand the target language in a careful traded progression. This has helped the learner to understand the target language stage for stage. Brown (Brown: 2007) has explained that the direct method focuses the learner on the drilling of the target language exclusively. The drills may be in form of questions and answer or through modelling or practice. Therefore, through this strategy, the students were led to the target language directly which eases their learning process.

As for dialogue completions, dialogue memorization, repetition drill strategy, they have helped the students to shape their thinking pattern through the repetition and reinforcement of the target language. Regarding to this strategy. Audio-lingualism relied heavily on drills to form these habits; substitution was built into these drills so that, in small steps, the students was constantly learning and, moreover, was shielded from the possibility of making mistakes by the design of the drills. Further, when the teacher used simulation strategy in her teaching, she has helped the students to implement the target language that they have learned into real situated practice. This had definitely helped the students to imagine as if they were in the situations described by the teacher. Strategy using Task Based Language Teaching (TLBT) can be implemented by assigning tasks that are connected to the real world communication practice and providing roleplay activities that involve problem solving, simulation and many other communicative activities (Nunan: 2004). Therefore, by using simulation and assigning communicative strategies, the students have been assisted to practice their target language into more comprehensive and more real world communication. 
Nonetheless, even though the activities provided were various, some students were still sleepy and not very attentive to the lesson. In this case, the teacher provided the students with some fun activities such as Chinese whisper, chain story and hot potatoes to get the students concentrate on the lesson again. In communicative language teaching, those activities are called the language games strategy. Language learning activities in the form of language games not only help to foster learners' interest in language learning but also help to teach new items, practice language forms and revise what has been learned before to speed up learners' pace of language acquisition (Saha, S, Singh, S: 2016). This language games have helped the teacher to keep the students focus on the lesson and make them awake when they were sleepy.

\section{CONCLUSION AND RECOMMENDATION}

The English teacher has implemented various strategies to accommodate the teaching and learning process in the eleventh grade students. She also integrates the K-13 teaching approach with the strategies of teaching English from diverse teaching methodology such as: Grammar Translation Method, Audio-Lingual Method, Communicative Language Teaching, and Task Based Language teaching. In other word, it could be said that the English teachers in one of these days could not rely on one specific method in presenting their materials. However, they must be able to accommodate many different strategies from many different methods that they think are suitable and applicable for their class. The strategies in assisting the students in learning English has been working well. The teacher knows her roles from the controller, prompter, the manager, and the facilitator. In addition, to counter the students' distraction in learning English due to sleepiness and fatigue, the teacher implemented the language games strategy which was derived from the communicative language teaching. The implementation of this strategy has made the students' mind back on track in absorbing the lesson. This research mainly provides information on strategies that the teacher used in teaching English to the students by considering the students' physical fatigue, varied English competence, and learning motivation. However for further research, the writer would recommend to give deeper analysis on students' learning style to see how each learning style in teaching affect the teaching strategies and to provide more information on dominant learning style that owned by the students in the Islamic boarding school.

\section{REFERENCES}

Abbasi Malik Abdul, P. (2011). A Survey of Teaching Strategies in ESL Classroom. Language in India, 313-329.

Bonnie Piller, M. J. (2005). English Language Teaching Strategies Used by Primary Teachers in One New Delhi, India School. TESL-EJ, 10.

Brown, H. D. (2000). Teaching by Principles: An Interactive Approach to Language Pedagogy (Second ed.). New York: Pearson Education Inc.

Brown, H. D. (2007). Principles of Language Learning and Teaching (Fifth ed.). New York: Pearson Education, Inc.

Creswell, J. W. (2009). Research Design: Qualitative, Quantitative, and Mixed Methods Approaches (3rd ed.). California: Sage Publications, Inc.

Dzanic, N. D. (2016). The Effect of Using Songs On Young Learners and Their Motivation for Learning English. NETSOL: Interdisciplinary Journal, 40-54. 
Fraenkel R. Jack, Wallen E. Norman, Hyun H Helen. (2012). How to Design and Evaluate Research in Education. New York: McGraw-Hill.

Freeman, D. L. (2008). Techniques and Principles in Language Teaching. (R. N. Rutherford, Ed.) New York: Oxford University Press.

Harmer, J. (2007). How to Teach English (New Edition ed.). Harlow: Pearson Education Limited.

Harmer, J. (2007). The Practice of English Language Teaching. Harlow: Pearson Education Limited.

Irby J. Beverly, e. (2018, May). Implementation of Research-based ESL Strategies with Lower Grade Middle School ELLs in the Science Classroom: Findings from an Experimental Study. TESLEJ, 1,14 .

Lodico G. Marguerete, Spaulding T. Den, and Voegtle H. Katherine. (2010). Methods in Educational Research: From Theory to Practice (2nd ed.). San Francisco: John Wiley \& Sons, Inc.

Mack Natasha, Woodsong Cynthia, MacQueen M, Kathleen, Guess Greg and Namey Emily. (2005). Qualitative Research Methods: A data Collector's Field Guide. North Carolina: Family Health International.

Nunan, D. (2004). Task-Based Language Teaching. New York: Cambridge University Press.

Pendidikan, W. M. (2014). Konsep dan Implementasi Kurikulum 2013. Jakarta: Kementerian Pendidikan dan Kebudayaan.

Richard, C. Jack and Theodore S. Rodgers. (2001). Approaches and Methods in Language Teaching (2nd ed.). Cambridge: Cambridge University Press.

S. Archana \& K. Usha Rani. (2017). Role of Teacher in English Language Teaching (ELT). International Journal of Educational (IJESR), 1-4.

Singh, S. (2016). Game Based Language Learning in ESL Classroom: A Theoretical Perspective. International E-Journal for Research in ELT, 20-34.

Thomson, N. (2012). Language Teaching Strategies and Techniques Used to Support Students Learning in a Language other than Their Mother Tongue. Kongsberg: International Baccalaureate Organization. 